\title{
Comparative study on the biomass yield, chemical composition and in- sacco dry matter degradability of different cultivars of triticale fodder
}

\author{
MK Zannat ${ }^{1}$, MR Alam ${ }^{3}$, NR Sarker ${ }^{2}$, KS Huque $^{2}$, MRI Khan $^{1}$ and MA Islam ${ }^{2}$ \\ ${ }^{1}$ Department of Animal Science, Bangladesh Agricultural University, Mymensingh 2202 \\ ${ }^{2}$ Bangladesh Livestock Research Institute, Savar, Dhaka 1341 \\ ${ }^{3}$ School of Sustainable Agriculture, University of Malaysia, Sabah, Malaysia
}

\begin{abstract}
An experiment was conducted to determine the biomass yield, chemical composition and in-sacco dry matter (DM) degradability of 10 cultivars (WRF-7, TSN-111, TYT-03, TYT-05, TYT-06, TYT-08, TYT12, ITYN-10, ITYN-14 and ITYN-15) of triticale fodder. The fresh yield of different cultivars of triticale was ranged from 5.03 to 6.85 (t/ha). The organic matter (OM), crude protein (CP), acid detergent fibre (ADF), neutral detergent fibre (NDF), calcium (Ca) and phosphorus (P) contents of different cultivars of triticale were found 89.62 to $91.78 \%, 21.34$ to $25.99 \%, 23.09$ to $29.99 \%, 46.77$ to $50.80 \%, 0.42$ to $0.61 \%$ and 0.33 to $0.41 \%$, respectively. The yield of DM and CP of different cultivars of triticale were varied from 0.77 to 1.44 (t/ha) and 0.193 to 0.351 (t/ha), respectively. Among different triticale cultivars the highest OM and CP contents were found in TYT-12 (91.78\%) and ITYN-10 (25.99\%), respectively. The highest NDF and ADF contents were found in ITYN-14 (50.80\%) and TYT-05 (29.99\%), respectively among different cultivars. The contents of Ca and P in ITYN-10 $(0.61 \%)$ and ITYN-14 $(0.41 \%)$, respectively were found to be the highest among the cultivars. Potential DM degradability observed in different cultivars of triticale was higher in ITYN-14 and TYT-05 (84.81 and $81.88 \%$, respectively) compared to others and relatively poor degradability was found in TSN-111 and TYT-03 (60.74 and $61.35 \%$, respectively). Therefore, it may be concluded that, the cultivar ITYN-10 will be the promising one due to comparatively higher fresh yield, organic matter (OM), crude protein (CP), neutral detergent fibre (NDF), calcium (Ca) and phosphorus (P) content and less acid detergent fibre (ADF) fraction cultivated for fodder production in Bangladesh.
\end{abstract}

Key words: Triticale, Cultivation, Nutrient composition, in-Sacco Degradability.

Bangladesh Animal Husbandry Association. All rights reserved.

Bang. J. Anim. Sci. 2012. 41 (1): 24-28

\section{I ntroduction}

Ruminant livestock, the source of high quality nutritional food such as milk and meat for human is considered as an integral part of farming system in Bangladesh. The major feed for livestock in Bangladesh is straw. About $2 \mathrm{~kg}$ of straw is available per head per day and supplementation is limited to about $1 \mathrm{~kg}$ of green fodder plus marginal quantities of cereal and oilseed by-products. Scarcity of forage is one of the major constraints of livestock farming in Bangladesh. In the prevailing cropping systems, supply of adequate feed is far less than their requirements for various productive purposes. Therefore, cultivation of high yielding fodders on short rotation in between the crops or along with the cash crops having multipurpose uses may offer promising to the farmers to grow fodder crop for livestock (Alam et al. 2007). Triticale (X Triticosecale
Wittmack), a cereal grain is the product of crosses between wheat (Triticum aestivum) and rye (Secale). It appears to be particularly promising crop due to its high yield potential, drought tolerant, and disease resistant (Saade 1995) associated with their wide adaptability and stable yield (Anonymous 1995). Unlike many cereal crops, one of the important characteristics of triticale is the yield of multiple products to farmers such as grain, green forage and straw. It has also higher protein content than oats and higher forage and silage yields than oats, barley, wheat, and rye (CIMMYT, 1986). Triticale is usually grown during lean period when no green fodder is available to the farmers. Therefore, triticale may be an alternate forage crop for livestock in Bangladesh. An investigation on yield and nutritive values of different cultivars of triticale in Bangladesh environment is required to recommend for its potential use as feed for 


\section{Degradability of triticale}

ruminants. Therefore, the study was undertaken to investigate the potential biomass yield, chemical composition, and in-sacco dry matter (DM) degradability of different cultivars of triticale.

\section{Materials and Methods}

The study was conducted with 10 cultivars (WRF-7, TSN-111, TYT-03, TYT-05, TYT-06, TYT-08, TYT-12, ITYN-10, ITYN-14, and ITYN15) of triticale at Bangladesh Livestock Research Institute (BLRI), Savar, Dhaka from 16 November, 2008 to 18 March, 2009. The study involved in the determination of biomass yield, chemical composition and in- sacco DM degradability of triticale cultivars.

\section{Method of cultivation}

Land preparation consists of one deep plaguing followed by 3-4 disking. Weeds and stubbles were removed from the soil and leveled properly. The whole land was divided into 40 plots having $12 \mathrm{~m}^{2}$ each. Fertilizer was applied at the ratio of 140:60:40:20 NPKS/ha. During land preparation, Triple Super Phosphate (TSP, ) Murate of Potash (MP) and Gypsum were applied at the rate of 130,70 and $110 \mathrm{~kg} / \mathrm{ha}$, respectively. All the plots received cow dung as basal dose in addition. Triticale seeds were sown on November 16, 2008 in rows by line sowing method with $20 \mathrm{~cm}$ row spacing. Weeding and irrigation to all the plots were done two times during experimental period. Harvesting of forage was done at 35 days of growth. Each plot was kept for further growth of vegetation, the green forage was harvested and the 2nd time at 50th day of plantation for obtaining total biomass yield in each plot. Immediate after each harvesting, the fodders were weighed and green forage yield was recorded.

\section{Collection of Samples}

During first and second harvesting, the representative samples of triticale fodder were collected at random from each treatment plot. After collection, they were kept in the polythene bags and stored in the freeze for further processing. At the same time, freshly collected 5 representative plants from each plot was chopped into small pieces and kept for determining dry matter content of the forage. Samples were ground in a grinding machine at the size of $1.0 \mathrm{~mm}$ and $0.5 \mathrm{~mm}$. The ground samples were bottled covered and kept in desiccator.

\section{Chemical analysis}

Chemical composition of samples for organic matter (OM) and crude protein (CP) were estimated according to the method of AOAC (2003). Neutral detergent fiber (NDF) and acid detergent fiber (ADF) were estimated following the methods of Faichney and White (1983). Calcium ( $\mathrm{Ca}$ ) and Phosphorus (P) were determined by the method of Olsen and Sommers (1982).

\section{In Sacco Degradability}

Dried ground triticale fodder samples were used for the determination of DM degradability in the rumen of bulls according to the method of Mehrez and Ørskov (1977). Three adult bulls of about $170 \mathrm{Kg}$ live weight with an average age of 4 years and fitted with permanent rumen fistula were used for the experiment. The bulls were kept in individual pen under appropriate hygienic condition. A diet composed of roughages $(70 \%)$ and concentrates (30\%) having $7.5-8.0 \% \mathrm{CP}$ to meet their maintenance requirement during the adjustment period (10 days) and the experimental period. The roughage and concentrate contained $35 \%$ rice straw, 35\% Dal grass and 18\% wheat bran, $11.5 \%$ rice polish and $0.5 \%$ common salt respectively. Clean water was supplied to all animals abundantly.

\section{Statistical analysis}

The data were analyzed using the GENSTAT Statistical Program for a completely randomized design (CRD), and differences among the treatment means were determined by the Least Significant Difference (LSD).

\section{Results and Discussion}

\section{Yield of different cultivars of triticale}

The biomass yield of different cultivars of triticale is shown in Table 1 . The fresh biomass production and dry matter yield of the different triticale cultivars ranged from 5.03 to $6.85 \mathrm{t} / \mathrm{ha}$ and 0.77 to $1.44 \mathrm{t} / \mathrm{ha}$, respectively. But the values of biomass yield or dry matter (DM) content were statistically significant $(p<0.05)$ among the different cultivars of triticale. Similar 
trend was also found in case of crude protein (CP) yield.

Table 1. Biomass yield of different cultivars of triticale

\begin{tabular}{lccc}
\hline Cultivars & $\begin{array}{c}\text { Fresh biomass } \\
\text { yield (t/ha) }\end{array}$ & $\begin{array}{c}\text { DM yield } \\
(\mathrm{t} / \mathrm{ha})\end{array}$ & $\begin{array}{c}\text { CP yield } \\
(\mathrm{t} / \mathrm{ha})\end{array}$ \\
\hline WRF-7 & $6.09^{\mathrm{d}}$ & $1.31^{\mathrm{c}}$ & $0.294 \mathrm{c}$ \\
TSN-111 & $5.03^{\mathrm{i}}$ & $0.77^{\mathrm{g}}$ & $0.197^{\mathrm{g}}$ \\
TYT-03 & $6.85^{\mathrm{a}}$ & $1.44^{\mathrm{a}}$ & $0.316^{\mathrm{b}}$ \\
TYT-05 & $5.63^{\mathrm{f}}$ & $0.77^{\mathrm{g}}$ & $0.193^{\mathrm{g}}$ \\
TYT-06 & $5.32^{\mathrm{h}}$ & $1.15^{\mathrm{e}}$ & $0.258^{\mathrm{e}}$ \\
TYT-08 & $5.92^{\mathrm{e}}$ & $0.86^{\mathrm{f}}$ & $0.217^{\mathrm{g}}$ \\
TYT-12 & $5.48^{\mathrm{g}}$ & $1.14^{\mathrm{e}}$ & $0.243^{\mathrm{f}}$ \\
ITYN-10 & $6.41^{\mathrm{b}}$ & $1.35^{\mathrm{b}}$ & $0.351^{\mathrm{a}}$ \\
ITYN-14 & $6.25^{\mathrm{c}}$ & $1.21^{\mathrm{d}}$ & $0.314^{\mathrm{b}}$ \\
ITYN-15 & $6.13^{\mathrm{d}}$ & $1.19^{\mathrm{d}}$ & $0.270^{\mathrm{d}}$ \\
\hline SE & 0.08 & 0.04 & 0.01 \\
\hline SE, Standard & error; & Means with & different
\end{tabular}

superscripts in the same column differ significantly $(p<0.01)$

Fresh and DM yield provides an assessment of forage production to determine the number of animal can be reared per unit of land. The fresh and DM yield of different cultivars of triticale found in this experiment was higher and, or similar to the reports of Sultana et al. (2005), Khan et al. (1996), Rajput and Singh (1996) and Rahman. (2009). It is evident that the triticale may be one of the important sources of fodder to meet the demand for rearing higher number of ruminants per unit of land and may provide opportunity to utilize triticale as fodder crops. In addition to gain production, all the cultivars may be cultivated in the dry season (November to March) when green vegetation is scared.

\section{Chemical composition of different cultivars of triticale}

The chemical composition of different cultivars of triticale is given in Table 2 . The OM, CP, NDF, $A D F, C a$, and $P$ content, in different cultivars of triticale were varied from 89.62 to $91.78 \%$, 21.34 to $25.99 \%, 46.77$ to $50.80 \%, 23.09$ to $29.99 \%, 0.42$ to $0.61 \%$ and 0.33 to $0.40 \%$, respectively at 35 days of growth. Only 2-3\% difference in DM content and $0.5-3 \%$ difference in OM content were observed among different cultivars of triticale. There is a variation of 2 4\% CP content, 1-4\% NDF content, 1-6\% ADF content, $0.01-0.21 \% \mathrm{Ca}$ content and 0.01 -
$0.07 \% \mathrm{P}$ content among the different cultivars of triticale.

Table 2. Chemical composition of triticale (\% DM) at 35 days of growth

\begin{tabular}{|c|c|c|c|c|c|c|}
\hline \multirow[t]{2}{*}{ Cultivars } & \multicolumn{6}{|c|}{ Nutrients (\%) on DM basis } \\
\hline & $\overline{\mathrm{OM}}$ & $\mathrm{CP}$ & NDF & ADF & $\mathrm{Ca}$ & $P$ \\
\hline 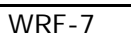 & $90.80^{h}$ & $22.41^{g}$ & $46.77^{h}$ & $23.18^{i}$ & $0.44^{c}$ & 0.33 \\
\hline TSN-111 & $91.54^{\mathrm{b}}$ & $25.54^{c}$ & $49.05^{e}$ & $29.65^{b}$ & $0.45^{c}$ & 0.35 \\
\hline TYT-03 & $91.26^{\mathrm{e}}$ & $21.95^{h}$ & $50.60^{b}$ & $23.09^{j}$ & $0.48^{\mathrm{c}}$ & 0.36 \\
\hline TYT-05 & $89.62^{j}$ & $25.05^{e}$ & $49.07^{e}$ & $29.99^{a}$ & $0.60^{\mathrm{a}}$ & 0.38 \\
\hline TYT-06 & $91.05^{\mathrm{g}}$ & $22.40^{\mathrm{g}}$ & $48.14^{\mathrm{g}}$ & $23.7^{f}$ & $0.54^{\mathrm{b}}$ & 0.34 \\
\hline TYT-08 & $90.61^{i}$ & $25.19^{d}$ & $49.67^{d}$ & $28.07^{f}$ & $0.43^{c}$ & 0.33 \\
\hline TYT-12 & $91.78^{a}$ & $21.34^{i}$ & $50.17^{c}$ & $23.52^{h}$ & $0.42^{d}$ & 0.39 \\
\hline ITYN-10 & $91.42^{c}$ & $25.99^{\mathrm{a}}$ & $49.73^{d}$ & $28.39^{\mathrm{e}}$ & $0.61^{\mathrm{a}}$ & 0.40 \\
\hline ITYN-14 & $91.15^{f}$ & $25.91^{b}$ & $50.80^{\mathrm{a}}$ & $26.74^{g}$ & $0.44^{c}$ & 0.41 \\
\hline ITYN-15 & $91.34^{d}$ & $22.67^{f}$ & $48.00^{f}$ & $28.59^{d}$ & $0.49^{c}$ & 0.39 \\
\hline$\overline{S E}$ & 0.09 & 0.28 & 0.19 & 0.40 & 0.01 & 0.01 \\
\hline
\end{tabular}

Chemical composition of forage provides information on their nutrient content but alone it can be a sole indicator of nutritional values. The values provides information on potential nutrient content but unable to indicate the form of availability of nutrients. The content of OM is similar to the report of Khandaker (2007) in Ipilipil and Islam (2003) in Sesbania and Leucaena. The average content of $\mathrm{CP}$ in the present experiment was similar to the value of $24.0 \%$ for triticale (Islam et al. 2003) for Ipilipil fodder (Rahman 2006) and (Khandaker 2007), and 20 to $21 \%$ for Sesbania and Leucaena leaves (Islam 2003). Rashid (2010) found nearly $10 \%$ CP in triticale fodder. Higher $\mathrm{CP}$ content observed in this experiment may be due to all the cultivars used in this trial are of fodder variety and higher proportion of leafy biomass may have cultivated to contain more $\mathrm{CP}$. It is apparent that cultivation of different cultivars of triticale would provide higher biomass and CP yield to be used for feeding ruminants similar to other leguminous and nonleguminous fodder crops. The content of NDF found in the experiments was high to the values reported by Rahman (2006) for Ipilipil and Islam (2007) for Gama, Oat and Sorghum fodders. Values obtained for ADF content were agree with the values reported by Rahman (2006) for I pilipil but lower compared to Gama, Oat and Sorghum fodders (Islam, 2007). The contents of NDF and ADF indicate the proportion of easily and less digestible fiber fraction, respectively. Thus, triticale at 35 days 


\section{Degradability of triticale}

of harvest appeared to contain more digestible fraction of fiber and digestibility of plant materials may not be affected by the presence of indigestible fiber fractions. The average $\mathrm{Ca}$ content in this experiment is similar to the values reported by Rahman (2006) for I pilipil, Calliandra and Gliricidia but high in P content. It may be assumed that these triticale cultivars may be one of the sources of these minerals to ruminants to meet their requirements if fed adequately.

\section{In-sacco DM degradability}

It appeared that the rate constant soluble fraction of feed varied from 4.22 to $9.02 \%$ among the different cultivars of triticale (Table $3)$. The extent of DM degradability was differed by 54.68 to $75.24 \%$ among the different cultivars. The rate of degradation of DM also varies from 3.6 to $5.6 \%$. The values for potential degradability of DM was appeared high and ranged from 61 to $75 \%$. It appears that all the varieties of Triticale are good quality fodder and may provide readily soluble nutrients and may reach to high digestibility potentials by ruminants.

Table 3. In-sacco DM degradability of different cultivars of triticale

\begin{tabular}{lcccc}
\hline Cultivars & \multicolumn{4}{c}{ Parameters } \\
\cline { 2 - 5 } & $\mathrm{a}$ & $\mathrm{b}$ & $\mathrm{c}$ & $\mathrm{a}+\mathrm{b}$ \\
\hline WRF-7 & 6.42 & 56.66 & 0.056 & 63.08 \\
TSN-111 & 6.06 & 54.68 & 0.053 & 60.74 \\
TYT-03 & 4.22 & 57.13 & 0.046 & 61.35 \\
TYT-05 & 9.07 & 72.81 & 0.036 & 81.88 \\
TYT-06 & 9.02 & 71.56 & 0.038 & 80.58 \\
TYT-08 & 8.68 & 68.51 & 0.041 & 77.19 \\
TYT-12 & 6.66 & 66.88 & 0.044 & 73.54 \\
ITYN-10 & 7.32 & 70.79 & 0.042 & 78.11 \\
ITYN-14 & 4.97 & 75.24 & 0.040 & 84.81 \\
ITYN-15 & 8.24 & 68.49 & 0.039 & 76.73 \\
\hline
\end{tabular}

$a$, solubility of dry matter; $b$, extent of digestion; $c$, Rate of digestion; $a+b$, potential digestibility

Estimation of in-sacco degradability of forages is usually done for rapid screening of quality of large number of fodder samples. It provides values for prediction of digestible fraction of forages for ruminants. The soluble fraction, extend of degradation and potential degradability; all are indicative of the forms of nutrients and their digestibility once it is consumed by ruminants. Potential degradability observed in different cultivars of triticale ranged from 74.0 to $84.8 \%$, probably due to the contents of different proportion of digestible fiber particles which led to difference in degradation and subsequently potential degradation in the rumen. However, potential degradability of DM found in the experiment is similar to the reports of Alam et al. (2007) for Acacia and Sesbania. From the values obtained for easily soluble fraction, extend of degradation and potential degradation of triticale fodder it is apparent that the fodder may contain high soluble, digestible fractions and potential digestible ruminants and feeding to ruminant. Feeding of triticale to lactating cows was shown to increase daily milk yield, total solids, fat and protein by 7.1, 3.4, 3.6 and $5.6 \%$, respectively (Rashid 2010). The findings support the hypothesis for its potential use as fodder for increasing the productivity of livestock in the country. Therefore, feeding of triticale to the ruminants may provide adequate nutrients and may reach to potential intake and digestion. Further in vivo study is required to validate these findings. It is concluded that cultivation of different cultivars of triticale would yield higher biomass and contained higher nutritional values. In addition to grain production triticale may be one of the important sources of fodder for ruminants when availability of forages is less in dry season of the country.

\section{Conclusion}

On the basis of yield of fresh biomass and dry matter in addition to In-sacco DM degradability, it may be concluded that that TYT-03 is the best among different varieties of triticale (WRF-7, TSN-111, TYT-03, TYT-05, TYT-06, TYT-08, TYT-12, ITYN-10, ITYN-14, and ITYN-15). Moreover, ITYN-10 is a potential variety of triticale for its higher crude protein yield.

\section{References}

Alam MR, Amin MR, Kabir AKMA, Moniruzzaman $M$ and McNeil DM (2007). Effect of Tannis in Acacia nilotica, Albizia procera and Sesbania acculeata Foliage Determoned in vitro, in sacco and in vivo. Asian-Aust. J. Anim. Sci. 20: 220-228.

Anonymous (1995). Triticale Production and and Utilization in Tunisia: results of the farm survey. In CIMMYT economics working paper. P. 95-104.

AOAC (2003). Official Methods of Analysis ( $17^{\text {th }}$ Edn.) Association of Official Analytical Chemists, Washington DC, USA 
BBS (1991). Year Book of Agricultural Statistics of Bangladesh, 1989-90. Bangladesh Bureau of Statistics. Statistics Division, Ministry of Planning, Government of the Peoples Republic of Bangladesh.

CIMMYT. (1985). Triticale-a crop for marginal environments. Pages $72-80$ in CIMMYT Research Highlights 1985. CIMMYT, Mexico

Faichney GJ and White GA. (1983). Methods for the Analysis of Feeds Eaten by Ruminants. pp. 20-21. CSIRO: Australia division of animal production: Melbourne.

Islam N. (2007). Study on yield and nutritive values of Gama (Tripsacum dactyloides), Oat (Avena sativa) and Sorghum (Sorghum bicolor) forages for sheep. M.S. Thesis, Dept. of Animal Science, Bang. Agril. Univ., Mymensingh.

Islam S. (2003). Supplementation of tree foliages to cows for improving milk production in small holding farming systems. M.S. Thesis, Dept. of Animal Science, Bang. Agril. Univ., Mymensingh.

Khan MJ, Shajalal M and Sarker AR (1996). Yeild, Chemical composition and nutritive value of Oat (Avena Saliva) fodder at different levels of nitrogen fertilizer. Bang. J. Anim. Sci. 25: 109-115.

Khandaker NI (2007). A comparative study on growth of goats fed Ipil-ipil (Leucanea leucocephala) and Scavanging systems. M.S. Thesis, Dept. Animal Science, Bang. Agril. Univ., Mymensingh.

Mehrez AZ and Orskov ER (1977) A study of the artificial fiber bag technique for determining the digestibility of feeds in the rumen. Journal of Agricultural Science (Cambridge) 88: 654-650.

Olsen SR and LE Sommers (1982). Phosphorus. P. 403-430. In A. L. Page (ed.), Methods of soil analysis, Agron. No. 9, Part 2: chemical and Microbiological properties, $2^{\text {nd }}$ ed., Am. Soc. Agron., Madison, WI, USA.
Rahman H (2009). Effect of cow dung on Biomass yield of Triticale fodder at different seed rate. M.S. Thesis, Dept .of Dairy Science, Bang. Agril. Univ., Mymensingh.

Rahman MM (2006). Study on the nutritive values and in vitro Digestibility of some legume tree foliages. M.S. Thesis, Dept .of Animal Science, Bang. Agril. Univ., Mymensingh.

Rajput AL and Singh TP (1996). Response of nitrozen and phosphorus with and without rhizobium inoculation. Indian J. Agron. 36: 285-286.

Ranjan, S.K. (1980). Vikas Publishing. House Pvt. Ltd. New Delhi, India. Animal Nutrition in the tropics.

Rashid H (2010). Yeild of Triticale fodder and its effect on lactating animals. Paper presented in Annual Workshop of Bang. Agril. Univ. Research Systems held on 89 March, 2010. Bang. Agril. Univ. Mymensingh.

Saade ME (1995). Triticale production and Utilization in Tunisia: Constraints and Prospects. In: CIMMYT economics working paper. Mexico. P. 95-104.

Sarkar B (2000). Effect of different doses of nitrogen fertilizer on growth, yeild, chemical composition and degradibility of zamboo grass (Hybrid Jowar). M.S. Thesis, Dept. Animal Science, Bang. Agril. Univ., Mymensingh.

Shajalal M, Selim SM and Rahman A (1996). Effect of nitrogen fertilization on yield, chemical composition and Oat (Avena sayiva) fodder. Bangladesh J. Anim. Sci., 41: 65.

Sultana MN, Khan MJ, Khandaker ZH, and Uddin MM (2005). Effects of Rhizobium inoculum and nitrogen fertilizer on biomass production of cowpea (Vigna Unguiculata) forage at different stages of maturity. Bangladesh J. Agric. Univ. 3: 249-255. 